\title{
What Can Our Writing Do in the World?: The Feminist Praxis of Publishing Student Writing
}

by Danica Savonick

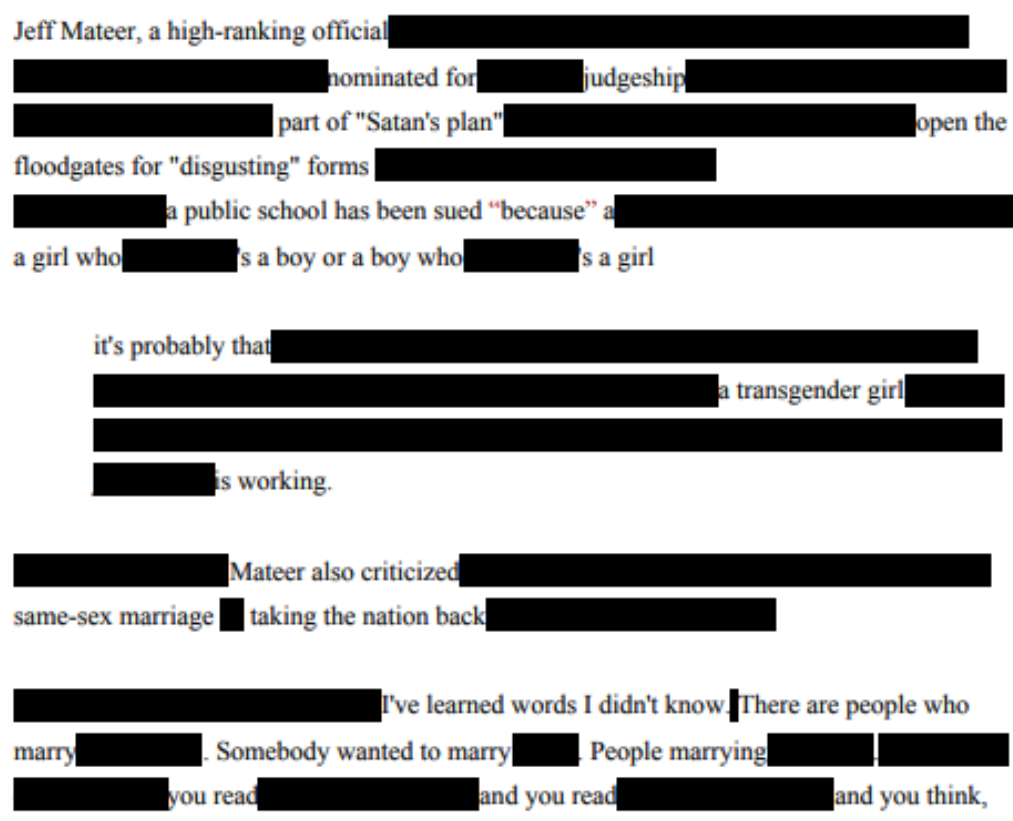

'Oh, that's not going on in our community.'

yes it is.

Last week, Trump nominated Mateer as a district judge on the U.S. District Court for the Eastern District of Texas.

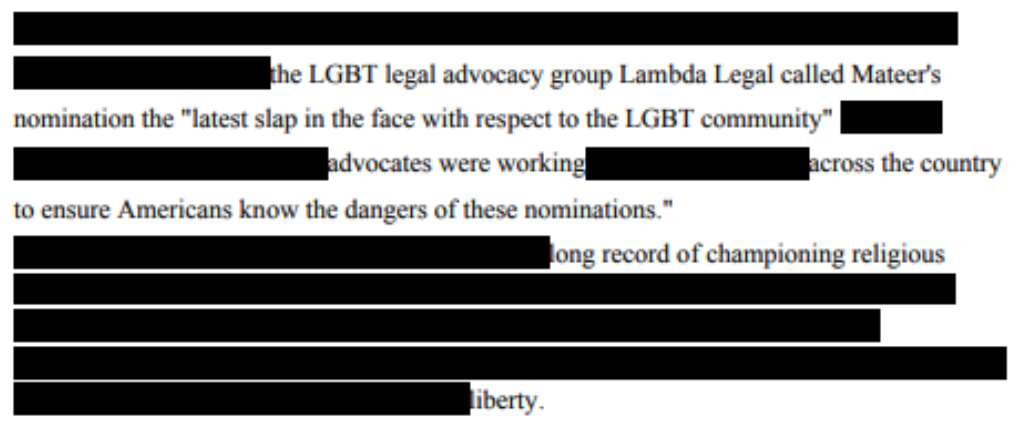

TAYLOR PRICE, "ERASING MATEER" 
F eminist pedagogy is an approach to learning that challenges social hierarchies, focuses on student empowerment, and addresses the uneven distribution of resources along embodied axes of race, class, gender, sexuality, and ability. Today, perhaps more than ever, we need feminist pedagogy, not only in Women's, Gender, and Sexuality Studies, but across the curriculum, including in general education and composition courses. In these (often required) courses, where students sometimes "don't like reading" and "aren't good at writing" (or so they think), we have a tremendous opportunity to think together about the power of language and the privileging of certain voices over others in society. In this article, I show how, rather than having students write solely for their instructor's eyes, publishing student writing for audiences beyond the classroom is a key component of feminist pedagogy, both historically and today.

In the digital age, scholars are increasingly arguing that one of the best ways to teach writing is by assigning students to write for audiences beyond the classroom (for instance, by writing blogs, articles, or editorials). In a 2007 longitudinal study, Andrea Lunsford and a team of researchers analyzed the writing practices of Stanford students over the course of five years and found that this generation of students values writing that makes something happen: "They write to shake the world" (Haven). And in her 2009 NCTE report, Kathleen Blake Yancey called for "public writing" as a crucial component of a composition pedagogy that prepares students to write in the 21st century. More recently, Cathy N. Davidson has advocated for these kinds of real-world writing assignments as part of a studentcentered approach to learning. And my own experiences have confirmed that having students write for audiences beyond the classroom generates increased investment in the work. And yet, this praxis of publishing student writing is not merely a response to the internet; it has been crucial to genealogies of feminist pedagogy.

This article addresses two questions laid out by the editors of this special issue on "Anti-Oppressive Composition Pedagogies": What are the afterlives of our students' writing? How can students start to see their work as valued? But in order to answer these complex questions, I begin by addressing another set: What are the histories of antioppressive pedagogy that inform your practice? How do we connect our pedagogy across generations? By attending to genealogies of feminist writing pedagogy, we can think in more nuanced terms about the transformative potential of publishing student writing today.

\section{Feminist Genealogies of Publishing Student Writing}

My adventures in feminist pedagogy are grounded in my research on the reciprocal relations between teaching and writing in the work of four famous feminist and antiracist authors: Audre Lorde, June Jordan, Toni Cade Bambara, and Adrienne Rich. In 1968, at the height of the Women's Movement, the Civil Rights Movement, Black Power, and protests against the Vietnam War (and the same year that Paulo Freire was writing his foundational Pedagogy of the
Oppressed), these authors were teaching down the hall from one another at Harlem's City College. While these figures are most often studied for their literature, my current book project Insurgent Knowledge positions them as theorists of feminist pedagogy who drew on their poetic sensibilities to develop student-centered, collaborative, and consciousnessraising pedagogies that transformed their classrooms into sites of social change. Influenced by educators and artists as diverse as Alfred North Whitehead, Mina Shaughnessy, and Amiri Baraka, they challenged students to make crucial decisions about the structure of their courses; to do original place-based research on poverty, housing, food, and education; to write and publish literature; and to become teachers in their classrooms and leaders in their communities. At the same time, the experience of teaching first generation, working class students of color in Open Admissions and educational opportunity programs fundamentally altered their writing and, with it, the course of American literature and feminist theory.

One way these teacher-poets took a feminist approach to classrooms was through publishing student writing, a praxis especially well-developed in the work of June Jordan and Toni Cade Bambara. To better understand this, it is useful to revisit four anthologies from the late 1960s and early 1970s edited by these authors, educators, and activists: The Black Woman, The Voice of the Children, Soulscript, and Tales and Stories for Black Folks. While these texts may be familiar to scholars of African American literature and Women's, Gender, and Sexuality studies, scholars rarely consider that all of these relatively wellknown anthologies included student writing. In fact, much of the writing in these collections emerged from the courses these authors taught at Tougaloo College, City College, Rutgers Livingston, and in less formal spaces, like weekend writing workshops. Instead of submitting writing solely to be read by the instructor, they organized their courses around the production of texts that could circulate in the world beyond the classroom.

I read these published collections, and their inclusion of student writing, as the enactment of a social justice pedagogy that addressed urgent social issues. For example, The Voice of the Children is a poetry collection authored entirely by students in Jordan's weekend writing workshops and published in 1970. In this collection, the young authors, ranging in age from twelve to fourteen, address the offensive and inaccurate stereotypes of illiterate "ghetto" children of color that were circulating in mainstream media in the late 1960s. Journalists regularly described these children as "silent creatures...[who] didn't know the names of things, didn't know that things had names, didn't even know their own names" (Holt 5). And yet, in just the first few pages of The Voice of the Children, the young authors respond to prompts such as "what would you do if you were president?" with trenchant critiques of ghetto stereotypes, settler colonialism, U.S. imperialism, and patriarchy, made all the more powerful when we consider that their average age was thirteen. In the opening prose poem, fourteen-yearold Vanessa Howard theorizes the power of stereotypes to reduce the complexity of individuals:

Nine out of ten times when a person hears the word 'ghetto' they think of Black people first of all...Ghetto 
has become a definition meaning Black, garbage, slum areas. To me the word 'ghetto' is just as bad as cursing. I think they put all Black people in a box marked 'ghetto' which leaves them having no identity. They should let Black people beseen for themselves, not as one reflection on all. (1)

In contrast to the top-down construction of traditional literary anthologies like the Norton, which are typically produced for but not by students in the classroom, Jordan and Bambara acted on a conviction that authorship - the power to move people through language - is widely distributed despite cultural institutions that privilege the voices of a narrow, white male elite. The authors they worked with were low-income, women with families to support, people of color, and often students (some as young as 9) and the editorial labor that went into these collections ranged from convincing publishers that these authors had something important to say to convincing the authors themselves. As educator-editors, they put in countless uncompensated hours corresponding with publishers, negotiating contracts, and organizing publicity events. They did so because they understood the multifaceted impact these anthologies could make in people's lives. These publications helped students understand the power of their voices and share survival strategies across the partitioning walls of classrooms and institutions; they addressed gaps in the cultural and literary record; and they called out to collectives of readers who had been ignored by publishers. Reflecting on a course that concluded with a collaborativelyauthored anthology, Jordan notes that "the class was producing its own literature: A literature reflecting the ideas and dreams and memories of the actual young Americans at work" ("Merit Review").

These anthologies were part of a grassroots movement for pedagogical, cultural, and social change that emerged not from top-down decisions by school boards, but led by writers and teachers embedded in city classrooms, who witnessed the pernicious gaps among existing curricula, the abundance of Black poetry, and the experiences of students' lives. In doing so, their feminist writing pedagogy drew on a long history of Black self-publishing, which was central to both the Harlem Renaissance and the Black Arts Movement. And it was from these experiences of trying to publish their and their students' writing that Kitchen Table: Woman of Color Press was later born.

But these anthologies are just some examples of the student writing these teacher-poets would publish. In Bambara's courses on subjects like "Colonialism, Neocolonialism, and Liberation," or "The Text as a Rite of Recovery," rather than dictating the forms their final projects should take, she often asked students to find or invent a form that would best tell the story of their learning and share these lessons with a public audience beyond the classroom. "Do not write term papers for me," Bambara told students, "Make sure they are useful for somebody else as well" (qtd. in Holmes 157), suggesting forms such as a collaborative annotated bibliography, performance art, a short story (for radio or TV), a magazine, puppet theater, a street theater performance, a slide show, or a picture book. The one requirement was that it "can be shared with others." Some examples of Jordan's collaborative projects include a
"Wrath Rally" and letter writing campaign against poverty in Biafra, organized by students in her Upward Bound Class, dramatic radio productions on children's welfare and racial justice in South Central Los Angeles, and A Revolutionary Blueprint, a collection of reading lists, syllabi, poetry, and activities that turned the lessons of her Poetry for the People program into a "how to guide" for others interested in democratizing poetry. Reflecting on what happens when students are asked not necessarily to write about literature, but to use what they learn about language through literature to move people to action, Jordan notes that "students' writing leaped into an eloquent fluency that had never even been hinted in their earlier work" ("Partisan Review" 481). Through these assignments, these teacher-poets taught students that their voices, stories, and actions mattered for social change; in short, that each student "has much to teach America" (Jordan Tomorrow).

As educators, we are accustomed to thinking about how our classes can be useful to students, but these teacherpoets urge us to consider how the classroom can also become useful to the world beyond its walls. They believed that everyone has something to contribute to the production of a more just, equitable, and pleasurable world, and that classrooms were one site for discovering what that might entail. Especially in their work with working class students of color, this often took the form of intervening in dominant narratives and getting better poems and books into the hands of readers who needed them. While I recognize the specificity of these projects and contexts, I also want to highlight their contributions to feminist pedagogy. Considered together, their work demonstrates how publishing student writing is not merely a response to the digital era, but has long been a component of feminist pedagogy, which encourages students to use what they are learning to make a positive impact in the world.

\section{Publishing Student Writing in the Digital}

\section{Era}

The genealogy of feminist publishing pedagogy analyzed in the previous section has prompted me to do things differently in my own writing and literature classrooms. Based on this research, I have reorganized my courses around the production of digital final projects, all of which challenge students to take what they learn and share it with a public audience. These projects have taken (at least) five different formats.

1. Composing poetry for their peers and college community

2. Submitting writing to an established, peerreviewed publication

3. Authoring public blogs for the academic network HASTAC.org

4. Making their learning useful for an audience beyond our classroom

5. Co-authoring a digital resource for other students, readers, writers, and educators 
In my Spring 2017 course on "The Arts of Dissent," at Queens College, I followed Bambara's lead in challenging students to find or invent a form that would best tell the story of something they had learned throughout the semester and make it useful to an audience beyond the classroom. I suggested formats like a digital poetry collection, timeline, or lesson plan. For this project, one group of students traveled to the Weeksville Heritage Center in Brooklyn - a museum and preserved 19th century African American community - to develop a lesson plan and assignment that would use the Center's resources and Langston Hughes' poem "Let America Be America Again" to teach high school students about racism and discrimination. Among the various writing and digital publishing platforms students were introduced to in class, this pair chose HASTAC.org, a free, open, and secure network of more than 16,000 scholars, students, artists, and activists committed to "changing the way we teach and learn." While one group used the software Tiki-Toki to create a historical timeline that would help readers better understand the acts of racial violence depicted in Claudia Rankine's Citizen: An American Lyric, another group drew inspiration from the very same literary text and used Wordpress to create their own poetry collection, "Citizen: An Urban Collegiate Lyric" containing original poetry based on their experiences at Queens College ("Citizen: An Urban Collegiate Lyric"). Although this was by no means a creative writing course, I have come to realize that writing is the experiential way of learning about literature and the power of language. On the final day of class, I presented students with a public, digital gallery of their projects ("Arts of Dissent Final").

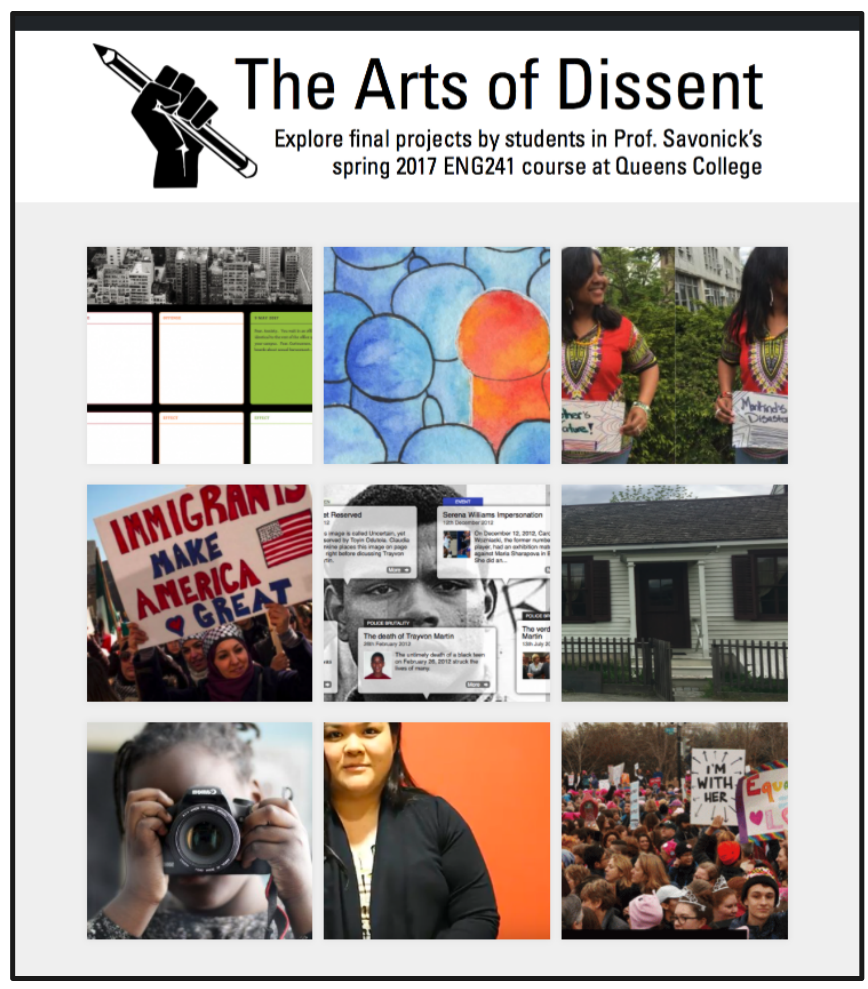

IMAGE 1: A PUBLIC, DIGITAL GALLERY OF PROJECTS PRODUCED BY STUDENTS IN PROF. SAVONICK'S SPRING 2017 COURSE ON "THE ARTS OF DISSENT." EACH IMAGE LINKS OUT TO A DIFFERENT PROJECT. HTTP://FUTURESINITIATIVE.ORG/ARTSOFDISSENTFINAL/
Currently, I teach at a public, regional university in Central New York, where the politics of publishing are quite different from those that I research. My students grew up with the internet, social media, and audiences at their fingertips. They read, write, and share their ideas constantly, though these daily writing practices are often in tension with the messages about writing they receive in schools in an era of high-stakes testing, dominated by the five paragraph essay. Whereas critical pedagogy has been rightly critiqued for its universalism, feminist pedagogy encourages us to attend to these differences and the situatedness, positionality, and particularity of our classrooms. What follows are two ways that I have continued to think about how publishing student writing can facilitate students' learning both about language and the intersecting axes of power.

One way I have used publishing to facilitate feminist pedagogy is by organizing my courses around questions of power, representation, and voice that directly impact my students' lives. I have twice taught a writing course on "The Purpose of Education," which immerses students in contemporary debates in education such as teaching and learning methods, assessment, unequal school funding, and technology in classrooms. So rarely are students' voices included in these debates even though they are the ones most affected by these conversations. This is, in part, because academic hierarchies dictate that students have little, if anything, to contribute to knowledge production. My course took up this issue by preparing students to author or co-author public pieces of writing on these subjects, either for the peer-reviewed journal Hybrid Pedagogy or the academic network HASTAC.org. For those who want to learn more about this assignment, I have written about the risks and rewards of digital publishing (Savonick "Write Out Loud") and have written a blog with detailed, step by step instructions (Savonick "Teaching Through Publishing").

This publishing assignment challenged students to think about how their learning can contribute to larger ongoing conversations in ways that are attentive to the intersecting axes of race, class, gender, sexuality, and ability. For example, in my students' blogs on technology in classrooms, they were asked to consider not only their own, personal relationships to the contemporary wave of "laptop bans" but also to consider how the prohibitive costs of laptops could produce unequal learning conditions and the effects of these bans on students with learning disabilities (see Dynarski and Pryal and Jack). Many students began their research projects either by liking laptops and saying that they should be allowed in classrooms or disliking laptops and saying that they should be banned. Through this writing project, I challenged students to consider not only their personal, idiosyncratic relationships, but to ask how, once published on the HASTAC.org website, different audiences might react to their argument. We discussed questions like: how might this argument sound to a reader with a disability? How might this sentence sound to someone who cannot afford a laptop? When I asked students why they performed exponentially better on this assignment than any of the others, their response was nearly unanimous: because they knew other people would be reading it. 
The internet has certainly made it easier to publish student writing, but sometimes "publishing," the act of making public, can be as simple as creating a hallway bulletin board (which $\mathrm{K}-12$ teachers are often much more savvy at than college professors). In general education courses like "Introduction to Multicultural Literature," I teach M. NourbeSe Philip's collection of found poems Zong! by having students create their own public gallery of found poems that document their relationships to current conditions of injustice. A found poem takes words, phrases, and passages from a source text and reframes them as poetry by making changes in spaces and lines, or by adding or deleting text, thus imparting new meaning. Philip's found poem takes as its source text the 1783 court case Gregson v. Gilbert, which determined whether slave owners would collect insurance money for the Africans thrown overboard and murdered in what has come to be known as the Zong massacre. After several class sessions analyzing poems in Zong!, students are instructed to bring in a text that makes them mad or upset, or that feels inaccurate or offensive, and to be prepared to write on it. While I suggest that a text related to injustice would work well, I do not insist upon it. As a result, students have brought in a wide range of texts, such as parking tickets, offensive song lyrics, biased news articles, and copies of their tuition bills. In class, students think critically about Philip's process of fragmenting, mutilating, and whiting out her source text by creating their own poems. Their resulting poems have addressed social issues ranging from sexual violence (we did this the week of Christine Blasey Ford's testimony against Brett Kavanaugh) and transphobia to police brutality against African Americans. Once complete, the poems are presented in a gallery to be viewed by anyone on campus.

Very few of the students who enroll in this general education course arrive with a pre-existing interest in poetry. Many think of it as boring, unnecessarily difficult, or intimidating. But this assignment brings poetry to life, encouraging students to use language and the space on the page to convey ideas about the world around them. Rather than having to write their own poem from scratch, conjuring words from thin air, this assignment allows students to create poetry by remixing and rearranging the words of others. While students spend the majority of the semester reading and analyzing literature, with this assignment, they become authors who craft poetry with messages they want to share with their peers. Knowing that their peers will be viewing their work gives the project a sense of urgency, allowing us to discuss how notions of audience and "reader reception" shape literature and how texts are embedded in a particular historical and social context.

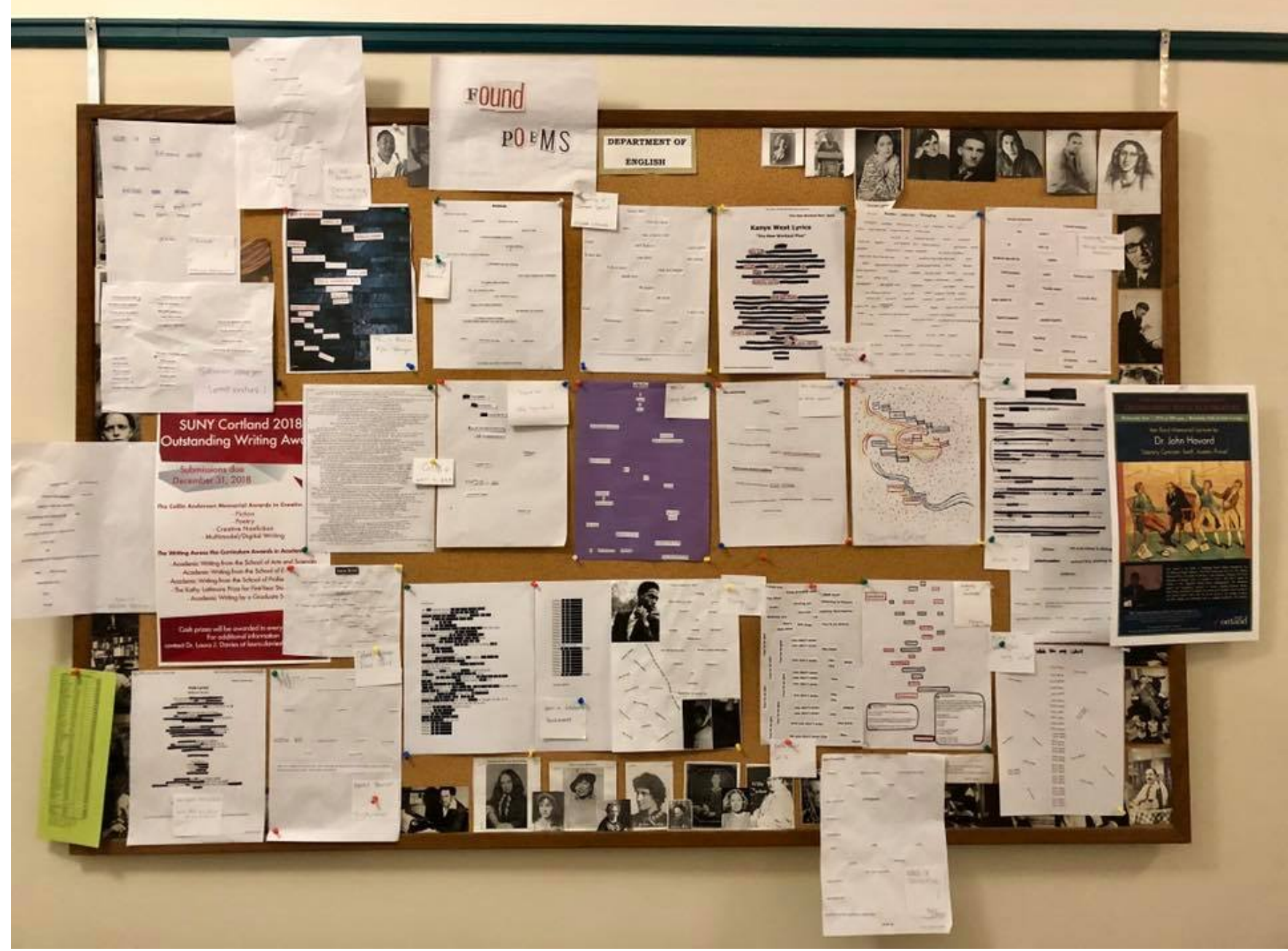

IMAGE 2: A BULLETIN BOARD OF STUDENT FOUND POEMS FROM STUDENTS IN TWO OF PROF. SAVONICK'S FALL 2018 SECTIONS OF "INTRODUCTION TO MULTICULTURAL LITERATURE." 


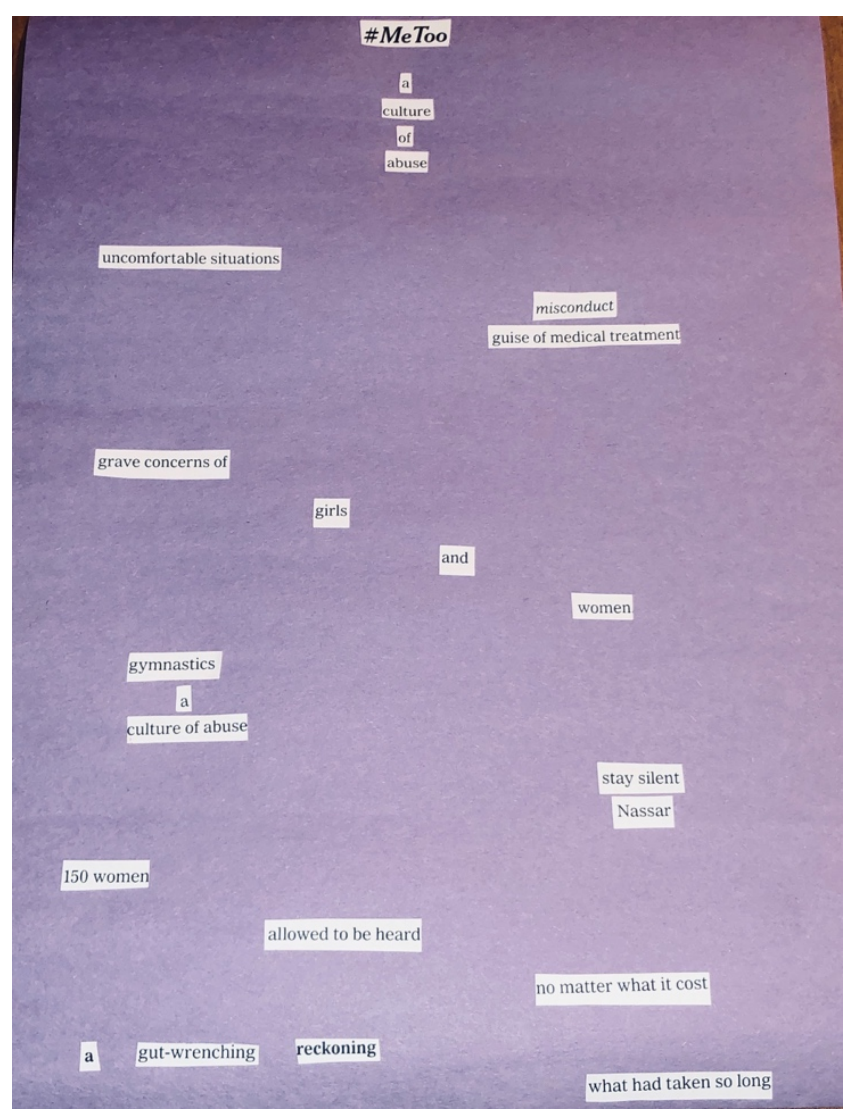

IMAGE 3: LACEY BARTLETT, "\#METOO"

Inevitably, the artists' statements students submit to accompany their poems always contain their sharpest insights regarding notions of authorial intent and the ways authors and readers collaborate to give meaning to a text. Reflecting on her poem "\#MeToo," created from a news article on the sexual violence perpetrated by gymnastics coach Larry Nassar, student Lacey Bartlett notes, "I decided to take pieces of the article and almost summarize what happened, with harsh words and fragments, and empty spaces to show that justice took too long. I included the 'stay silent/Nassar' part right before the part that says '150 women/allowed to be heard/no matter what it cost' just to reiterate the fact that this is about the women, not about the abuser." Another student, Taylor Price, created a poem from an article on Texas Attorney General Carl Mateer, who made derogatory remarks about transgender children and yet was nominated for a promotion to U.S. District Judge. Reflecting on this poem, Price notes that "I tried to black out as much of the hatred as I possibly could. I subverted the cruel statements by changing their focus."

To conclude, I join writing studies scholars who have shown how publishing can help students improve their writing because it taps into their desire to make things happen in the world. While students may enter our classrooms with an understanding that their compositions can solicit "likes," comments, retweets, and page views, a feminist perspective encourages us to see how this desire to make an impact can be channeled towards the production of a more just and equitable future. A feminist perspective encourages us to see the transformative potential of the question, what can our writing do in the world?
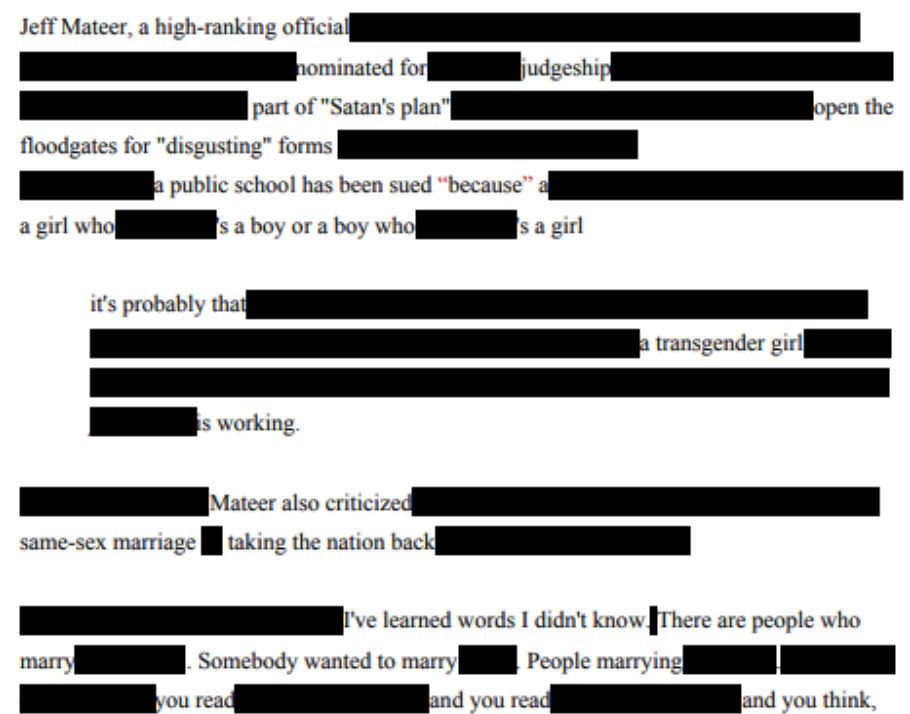

'Oh, that's not going on in our community.'

yes it is

Last week, Trump nominated Mateer as a district judge on the U.S. District Court for the Eastern District of Texas.

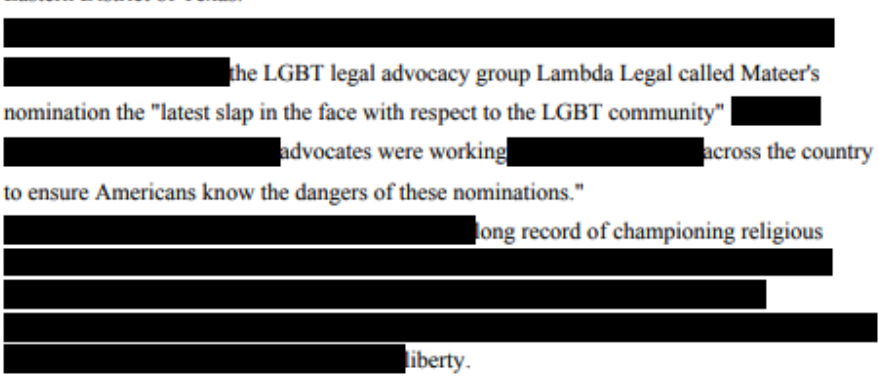

IMAGE 4: TAYLOR PRICE, "ERASING MATEER"

A note of thanks to Lacey Bartlett and Taylor Price for allowing me to include their poetry in this essay. 


\section{Works Cited}

Brittany, Kate, Lisette, and Angel, "Citizen: An Urban Collegiate Lyric" (https://collegiateurbanlyric.wordpress.com/)

Davidson, Cathy N. The New Education: How to Revolutionize the University for a World in Flux. Basic Books: 2017.

Dynarski, Susan. "Laptops Are Great. But Not During a Lecture or a Meeting." The New York Times, 22 Nov. 2017

https://www.nytimes.com/2017/11/22/business/lapto ps-not-during-lecture-or-meeting.html

Jordan, June. Merit Review Statement. 1993-1994. June Jordan Papers, Schlesinger Library Archive, Radcliffe Institute. Box 78, folder 8.

. "Writing and Teaching" Partisan Review Summer 1969, pp. 478-462.

. Editor. Tomorrow in English. June Jordan Papers, Schlesinger Library Archive, Radcliffe Institute. Box 76, folder 13 .

Jordan, June and Terri Bush, Editors. The Voice of the Children. Holt, Rinehart and Winston, Inc., 1968.

Haven, Cynthia. "The New Literacy: Stanford Study Finds Complexity in Students' Writing." Stanford News, 12 Oct.

2009.https://news.stanford.edu/news/2009/october12 /lunsford-writing-research-101209.html

Holmes, Linda Janet. "Lessons in Boldness" in Savoring the Salt: The Legacy of Toni Cade Bambara, edited by Linda J. Holmes and Cheryl A. Wall. Temple University Press, 2007.

Holt, John. Introduction. Teaching the 'Unteachable' by Herbert R. Kohl. The New York Review, 1967, pp. 5-10.

Howard, Vanessa. "Ghetto." Jordan and Bush, p. 1.

Ishakova, Julia and Rebecca Cameron. "Weeksville Through the Lens of Langston Hughes." HASTAC.org, 18 May 2017,

https://www.hastac.org/blogs/juliai96/2017/05/18/we eksville-through-lens-langston-hughes\#new_tab

Phillip, M. NourbeSe, Zong! Wesleyan University Press, 2008.

Pryal, Katie Rose Guest and Jordynn Jack, "When You Talk About Banning Laptops, You Throw Disabled Students Under the Bus." Huffington Post, 27 Nov. 2017 https://www.huffingtonpost.com/entry/when-you-talkabout-banning-laptops-you-throwdisabled us 5a1ccb4ee4b07bcab2c6997d

Savonick, Danica, ed. "The Arts of Dissent - Final." https://futuresinitiative.org/artsofdissentfinal/
. "Write Out Loud: Risk \& Reward in Digital Publishing." Hybrid Pedagogy, 8 Nov. 2017

. "Teaching Through Publishing." HASTAC.org, 29 Sep. 2017

https://www.hastac.org/blogs/danicasavonick/2017/0

9/29/teaching-through-publishing-scholarly-journalarticle-collaborative

Yancey, Kathleen Blake. "Writing in the 21st Century." Report from the National Council of Teachers of English, February 2009, http://www.ncte.org/library/NCTEFiles/Press/Yancey_fi nal.pdf (c) BY-NC-ND

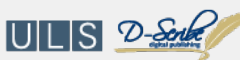

This work is licensed under a Creative Commons Attribution-Noncommercial-No Derivative Works 3.0 United States License.

This journal is published by the University Library System of the University of Pittsburgh as part of its D-Scribe Digital Publishing Program, and is cosponsored by the University of Pittsburgh Press. 